慶應義塾大学学術情報リポジトリ

Keio Associated Repository of Academic resouces

\begin{tabular}{|c|l|}
\hline Title & The development of gait from the viewpoint of temporal and distance factors \\
\hline Sub Title & \\
\hline Author & 高梨, 泰彦(Takanashi, Yasuhiko) \\
\hline Publisher & 慶應義塾大学体育研究所 \\
\hline Publication year & 1989 \\
\hline Jtitle & $\begin{array}{l}\text { 体育研究所紀要 (Bulletin of the institute of physical education, Keio } \\
\text { university). Vol.29, No.1 (1989. 12),p.95-95 }\end{array}$ \\
\hline JaLC DOI & \\
\hline Abstract & \\
\hline Notes & Abstract \\
\hline Genre & \\
\hline URL & https://koara.lib.keio.ac.jp/xoonips/modules/xoonips/detail.php?koara_id=AN00135710-0029000 \\
\hline
\end{tabular}

慶應義塾大学学術情報リポジトリ(KOARA)に掲載されているコンテンッの著作権は、それぞれの著作者、学会または出版社/発行者に帰属し、その権利は著作権法によって 保護されています。引用にあたっては、著作権法を遵守してご利用ください。

The copyrights of content available on the KeiO Associated Repository of Academic resources (KOARA) belong to the respective authors, academic societies, or publishers/issuers, and these rights are protected by the Japanese Copyright Act. When quoting the content, please follow the Japanese copyright act. 


\title{
The Development of Gait from the Viewpoint of Temporal and Distance Factors
}

\author{
By Yasuhiko Takanashi*
}

To determine the changes of normal free gait patterns in relation to aging, gait studies were performed on 146 normal male children and adults from the age of 6 to 86 years. The subjects were asked to walk at normal pace over an approximately 5-m walway system. The variables, measured automatically by the system, are cadence, walking velocity and step length. Reproducibility of step length was also calculated.

Cadence tends to decrease with age, but the rate of decrease is more rapid between age of 10 and $12 \mathrm{yr}$. Walking velocity and step length tend to increase rapidly in elementary school students, and get gradually constant between age of 13 and $15 \mathrm{yr}$. Reproducibility of step length advances rapidly between age of 7 and $9 \mathrm{yr}$. The twenties have nearly the same values of all the variables as the age of 15 years. The maturation of walking as determined by the variables is approximately at the age of $15 \mathrm{yr}$. Elder group (60 yr and older) has a significantly slower velocity and smaller step length than the youth (between $20 \mathrm{yr}$ and $39 \mathrm{yr}$ ).

* Assistant of the Institute of Physical Education, Keio University. 